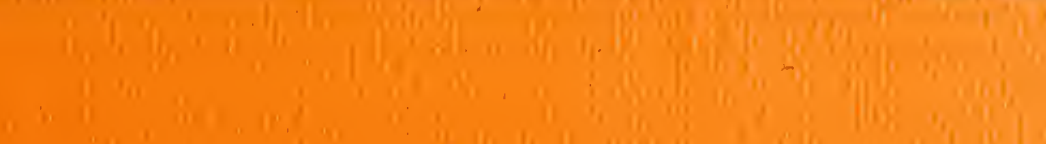

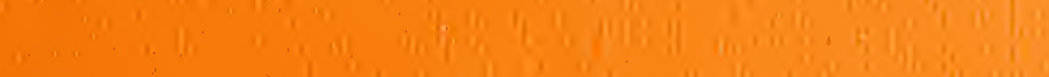

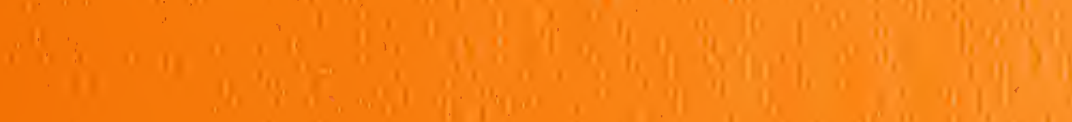

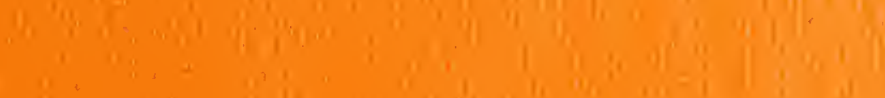

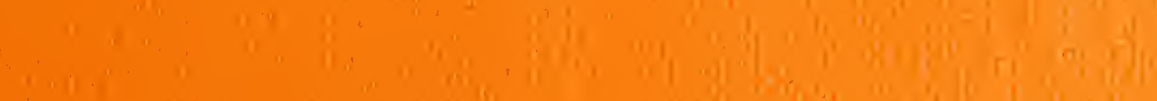

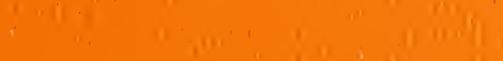
:
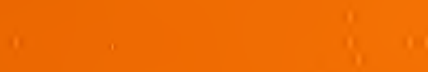

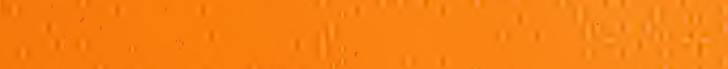

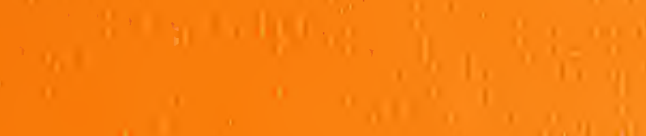
(1)

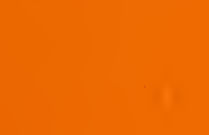





NBSIR 73-187

\section{The Effect of Impact Loadings on the Performance of Wood Joist Subflooring Systems}

H. S. Lew

Center for Building Technology

Institute for Applied Technology

National Bureau of Standards

Washington, D. C. 20234

May 1973

Final Report

Prepared for

Office of Research and Technology

Department of Housing and Urban Development

Washington, D. C. 20410 


\section{THE EFFECT OF IMPACT LOADINGS ON THE PERFORMANCE UF WOOD JOIST SUBFLOORING SYSTEMS}

H. S. Lew

Center for Building Technology

Institute for Applied Technology

National Bureau of Standards

Washington, D. C. 20234

May 1973

Final Report

Prepared for

Office of Research and Technology

Department of Housing and Urban Development

Washington, D. C. 20410

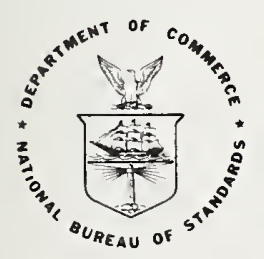

U. S. DEPARTMENT OF COMMERCE, Frederick B. Dent, Secretary

NATIONAL BUREAU OF STANDARDS, Richard W. Roberts, Director 


$$
\text { . }
$$


Impact Tests on Wood Joist Subflooring Systems by

H. S. Lew

Structures Section

Structures, Materials and Life Safety Division

Center for Building Technology, IAT

National Bureau of Standards

\begin{abstract}
This report presents the results of an experimental study of wood-joist subflooring systems subjected to impact load. Six different types of subflooring systems were tested following the test method described in the ASTM Standard Methods (ASTM Designation E-72). The magnitude of impact load was varied by dropping a $60-1 \mathrm{~b}$ bag from different heights.

A concentrated static load of $4001 \mathrm{~b}$ was applied to the subfloor after it was exposed to impact load. It is suggested that the deflection under this concentrated load be used as a measure of the impact resistance of the subfloor.
\end{abstract}

Key Words: Concentrated load; deflection; floor; hardboard; housing; impact energy; Operation BREAKTHROUGH; plywood; subfloors; underlayment; wood; wood joists. 
1. INTRODUCTION

1.1 Background

1.2 Scope

1.3 Test Program

1.4 Concentrated Load and Loaded Area

2. DESCRIPTION OF TESTS

2.1 Test Specimens

2.2 Test Setup

2.3 Test Procedure

2.4 Single Versus Successive-Impact Tests 10

3. TEST RESULTS AND DISCUSSIONS

3.1 Deflection From Concentrated Static Load

3.2 Impact Load versus F1oor Deflection From Concentrated Static Load

4. CONCLUSIONS

5. ACKNOWLEDGEMENTS

6. TABLES AND FIGURES

7. APPENDIX

8. REFERENCES 
In recognition of the position of the United States as a signatory to the General Conference of Weights and Measures, which gave official status to the metric SI system of units, the author assists readers interested in making use of the coherent system of SI units by giving conversion factors applicable to US units used in this paper.

\footnotetext{
Length

1 in $=0.0254$ metre $($ exactly)

$1 \mathrm{ft}=0.3048$ metre $($ exact $1 y)$
}

Area

1 in $^{2}=6.5416 \times 10^{-4} \operatorname{metre}^{2}(\operatorname{exact} 1 y)$

Mass

$11 \mathrm{~b}(1 \mathrm{bm})=0.4536 \mathrm{kilogram}$

I:nergy

$1 \mathrm{ft}-1 \mathrm{~b}(\mathrm{ft}-1 \mathrm{~b}$ force $)=1.356 \mathrm{joule}$ 
Hardboard:

A dense panelboard manufactured primarily of wood fibers with the natural lignin in the wood reactivated to serve as a binder for the wood fibers.

Subfloor:

The structural material or surface which supports floor loads and the finish flooring. If the subfloor material possesses sufficient density, smoothness, stiffness, dimensional, stablity, and adequate bonding properties, finish flooring may be applied directly on it without the use of underlayment.

Under 1 ayment:

A mastic or panelboard material installed over the subfloor to provide a suitable base for the finish flooring when the subfloor does not possess the necessary properties for direct application of the finish flooring. 


\section{INTRODUCTION}

\subsection{Background}

Performance criteria need both descriptive and quantified limits to adequately define their intent. It became apparent, in the course of the development of the Guide Criteria [1] I/ for the Operation BREAKTHROUGH program, that no reliable test data for conventional wood floors of dwelling construction are available to establish quantified limits relative to impact resistance. For this reason, the experimental program presented in this report was undertaken.

\subsection{Scope}

Because wood joist floor construction is widely used and has shown a generally acceptable level of performance, it was decided that the impact strength of wood-joist floors would provide an appropriate datum for comparison. The tests reported herein were carried out on wood-joist floors with several combinations of plywood subflooring.

\subsection{Test Program}

From the user's point of view, one feature of the serviceability of the floor is considered to be impaired when the local deformation of the floor is excessive

1/ The number in the bracket refers to the reference listed in Reference. 
under static loads. When an impact load causes damage to the floor, application of a static load on that part of the floor can produce a larger deflection than that produced by the same load on the undamaged floor at the same location. If this deflection under the static load is greater than a tolerable limit, the performance of this floor can become objectionable to the user. The serviceability of the floor would then be impaired.

The incidents which produce impact load in dwellings may range from accidental dropping of household items and furniture to a person falling from a ladder. The magnitudes of these impact loads on the floor have not been documented. Therefore, the resistance of floor systems to specific levels of impact loads associated with specific causes cannot be determined at present. On the other hand, deflection of the floor under a given static concentrated load can be determined experimentally relative to the stiffness reduction of the floor that might be caused by the application of impact load. Thus, for a limiting deflection under a given static concentrated load, the corresponding impact energy could be obtained for a specific floor system. Conversely, after being subjected to this maximum level of impact energy, the floor should not deflect more than a set limit under the same concentrated static load. 
A series of tests were made to establish a relationship between the impact load and the deflection at the impacted area under a concentrated static load. In each test, an impact load was applied to the specimen and subsequently the static deflection was measured under a concentrated load of predetermined magnitude applied to that area. The magnitude of the concentrated load and the size of the loaded area will be discussed in section 1.4 .

The impact was delivered to the specimen by dropping a 60-1b bag from a given height. For simplicity, the energy delivered to the specimen is measured by the product of the weight of the bag and the height of drop. Thus, the energy is expressed in terms of the potential energy rather than the kinetic energy delivered to the specimen. In this test program, the magnitude of impact energy is expressed in "ft$1 b . "$

1.4 Concentrated Load and Loaded Area

When concentration of load is considered for design, both the load and the loaded area should be taken into account. A study by Boyd [2] shows that typical concentrated loads found in houses are as follows: 
1. A person carrying a heavy 1oad... 350-400 1b

2. A crowded sofa (per front caster)... 300-350 1b

3. An upright piano (per caster). ..... 200 Ib

4. A player-piano (per caster)....... 280 lb

5. A hand-truck carrying an upright piano (per wheel)....... 250-350 1b

6. A hand-truck carrying a player-piano (per wheel)............350-4501b

Since the frequency of occurrence of a large load produced by such items as a player-piano is low, Boyd concluded that it would be inappropriate to design for such an extreme load. He suggested that it would not be unreasonable to consider a short-term load of $400 \mathrm{lb}$ for a duration of a few seconds over an area of $1.5 \mathrm{in}^{2}$. The magnitude of such a load appears reasonable to consider as a design load. However, the bearing pressure produced by this loading condition is substantially less than a maximum bearing pressure that could be expected from stiletto heels. It has been observed that due to a small contact area, silietto heels can produce a bearing pressure as high as 1,400 psi.

A test program that deals with evaluation of the performance of floors under concentrated load must consider both high magnitude loads and corresponding pressures that reflect what the floor would experience in practice. For 
this test program, it was decided to use a concentrated load of 400 lb applied over a 5/8-in dia. disc. This results in about $1,300 \mathrm{psi}$ of bearing pressure which is close to the upper range of bearing pressures that could occur in practice.

\section{DESCRIPTION OF TESTS}

\subsection{Test Specimens}

Four different groups of plywood subflooring were tested. Two groups consisted of a single sheet of plywood and two groups of a sheet of plywood overlayed with a sheet of underlayment (see glossary). To examine the effect of discontinuous edges of subflooring on the impact strength, the specimens with underlayment had both spliced sheets as well as full continuous sheets of plywood. Figure 1 illustrates the layout of the test specimens and table 1 gives a description of the specimens and the number of tests for each group.

All materials were typical of those presently used in conventional wood-frame house construction and were purchased from building material suppliers in the Washington, D. C. area. The plywood used for the specimens had five piles and met the Federal product Standard PS 1-66 for soft plywood [3]. Designations used to describe grades of the plywood used in this test program are given in the appendix. The hardboard underlayment satisfied the Federal Specification LLL-B-810a [4]. 
Al1 specimens were constructed in accordance with the provisions in FHA "Minimum Property Standards" (FHA-MPS) Sections 817.3 and 815.4 [5]. As shown in table 1, groups 1, 2, $3 a$ and $4 a$ specimens were constructed using full-size (4 ft $x$ $8 \mathrm{ft}$ ) sheets nailed on a frame made of $2 \times 8 \stackrel{2}{2}$ wood members. For group $3 b$ and $4 b$ specimens, a full-size sheet of plywood was first split into two halves of $2 \mathrm{ft} x 8 \mathrm{ft}$ and then nailed on the frame. A full-size (4 ft x $8 \mathrm{ft}$ ) sheet of underlayment was nailed on top of the plywood for all group 3 and 4 specimens. As specified in FHA-MPS, $8 d$ common nails were used for nailing the plywood. Six-inch spacing was used for interior and 10-in spacing for exterior joists. The underlayments were nailed directly on the plywood using $4 \mathrm{~d}$ annular-threaded nails spaced 6 inches on center in each perpendicular direction. For all test specimens, $2 \times 8$ joists were spaced at 16 inches on center, thus providing 6 equally spaced test panels (see fig. 1). The joists were end-nailed to the 2 x 8 edge members. The plywood sheet was oriented with the grain of the outer ply perpendicular to the axis of the joists. The 1etter designations A, B, C, and D shown in figure 1 indicate the test panels of each specimen on which the test load was applied. In all cases, tests were made on panels

2/ $2 \times 8$ is designation in nominal dimensions of wood joist whose actual cross-sectional dimensions are $1-1 / 2$ in by 7-1/2 in. 
$A$ and $B$ first. If the test on these two panels produced damage to either the plywood subflooring or the underlayment, the specimen was discarded. On the other hand, if no damage to the specimen was observed, additional tests were made on panels $\mathrm{C}$ and $\mathrm{D}$.

\subsection{Test Setup}

The test setup was essentially the same as the one described in ASTM E-72 [6] and is shown in figure 2. However, the test panel assembly was placed directly on the floor of the laboratory instead of placing it on steel roller supports as described in the ASTM test. This support condition minimized flexing action of the joist, thus providing a rigid support condition for impact loading. This also created a more severe test than if the joists were allowed to respond in flexure and hence, corresponded to a more critical situation in actual floors. The material and size of the 60-1b sandbag shown in figure 3 conformed to the specifications of ASTM E-72. The bag was dropped from a release-mechanism as shown.

The setup for the concentrated load test is shown in figure 4. The test load was applied by a single-acting hydraulic ram of 20,000-1b capacity. The load applied at a rate of one $1 \mathrm{~b} / \mathrm{sec}$ and was monitored by a load cell of 500-1b capacity. Al1 deformations under the concentrated load were measured using a rig shown in figure 5. The rig 
consisted of a 16-in long reference beam that spanned between two adjacent joists and a dial gage graduated to read 0.001 inch.

\subsection{Test Procedure}

Each group of the specimens described in table 1 was tested following two different test procedures. Part of the specimens of each group were tested under impact load only and the remaining specimens were subjected to both impact load and the static load of $400 \mathrm{lb}$. The significance of the static load test was described in section 1.3. The number of tests conducted under each test procedure for each group of specimens is given in table 2 .

For the specimens that were subjected only to impact load, residual deflection was measured at the center of the impacted area. The magnitude of impact, as defined by the product of the weight of the bag and the height of drop, was increased in increments of either $60 \mathrm{ft}-1 \mathrm{~b}$ or $120 \mathrm{ft}$ lb until breaking and/or splintering of the plywood subfloor was noted at the underside. For group 1 specimens, the test started from $60 \mathrm{ft}-1 \mathrm{~b}$ load and for other groups the test started from $120 \mathrm{ft}-1 \mathrm{~b}$ load. After the bag was removed from the specimen, residual deflections were measured on the top with respect to the top surface of test specimen as shown in figure 3 . 
Impact was repeated on a panel as long as distress was not observed anywhere in that panel. It should be pointed out that this procedure assumes that, as long as no breakings or splinterings are observed, the previous impact loads would not have damaged the test panel for the subsequent test, provided that the magnitude of the loads in the preceding tests were less than the subsequent test. This assumption is reasonable as it will be shown subsequently that no statistically significant difference was observed in residual deflections between those from successive impact load tests on the same test panel and those from single impact load tests where each increment of impact load was applied on a new test panel.

For those specimens which were subject to impact and the 400-1b static load, the following procedure was used. Prior to any load application, a reference deflection, designated as dl, was taken with the device shown in figure 5 . Next, a concentrated load of 400 lb was applied. After maintaining the load for one minute, a deflection reading, designated as $\mathrm{d} 2$, was taken while the load being applied on the top surface. After unloading and waiting for five minutes the top surface deflection, designated as d3, was again measured. The concentrated load was again applied, and maintained for one minute, and then the deflection, designated as d4, was measured under the load. The purpose of applying two cycles of loading was to minimize the indentation produced 
by the concentrated load. The deflection at the beginning of the second load cycle, d3, was used as a datum for a11 subsequent deflection measurements. Following the two static loading cycles, an impact load was applied on the same area which had received two cycles of static loading.

Deflections were measured before and after the impact, designated as $\mathrm{d} 5$ and $\mathrm{d} 6$, respectively, with the device shown in figure 3. The static load of 400 lb was again applied. As before, deflection measurements were taken before loading, while the load was being applied on the test panel and after unloading. They are designated as $\mathrm{d} 7, \mathrm{~d} 8$ and $\mathrm{d} 9$, respectively. Subsequent impact loading was applied in increments of either 60 or $120 \mathrm{ft}-1 \mathrm{~b}$. The deflection measurements $\mathrm{d} 5$ and d6 were taken with each application of impact load. Immediately following each application of impact load, the concentrated load of 400 1b was applied, and the deflection measurements d7, $d 8$ and $d 9$ were taken. This sequence was repeated until damage to the test panel was noted.

\subsection{Single versus Successive-Impact Tests}

Under the previously described scheme of testing, it was considered desirable to show that successive impact loading would not cause substantial cumulative damage to the subflooring. In order to verify this, two series of tests were performed on group 2 specimens. In one series 
of tests impact load was applied successively on the same panel until it broke. In another series of tests each impact load was applied on a separate pane1. The magnitude of impact load was increased and the residual deflections were measured after impact load in both series.

The residual deflection measurements of the two series of tests are compared at $360 \mathrm{ft}-1 \mathrm{~b}, 420 \mathrm{ft}-1 \mathrm{~b}$, and $480 \mathrm{ft}-1 \mathrm{~b}$ levels in table 3 . The measurements of single-impact tests are 1 isted under column $A$ and the measurements of successiveimpact tests under column B.

A two-sided statistical t-test was made to determine whether or not the averages of residual deflections of the two schemes differed significantly.. Although the distribution of measured values is not necessarily normal, the t-test procedure, as described in reference 7 , can still be used to give approximate result. It is assumed that the variances of the residual deflection measurements of the two schemes are not known and are not equal. The statistical quantities computed at a five-percent significance level corresponding to the $360 \mathrm{ft}-1 \mathrm{~b}, 420 \mathrm{ft}-1 \mathrm{~b}$, and $480 \mathrm{ft}-1 \mathrm{~b}$ levels are given in table 4 .

In comparing the means from each of the two testing schemes, a hypothesis is set up such that it is possible to discredit it from the facts. The hypothesis, in this case, is that the two sample means may be regarded as means of samples from the same population. The hypothesis is examined by testing whether the difference between the two means, 
$\tilde{x}_{\Lambda}-\bar{x}_{B}$, is significant. The computed statistics are compared with the absolute difference between the two means in the last row of table 4. It is seen here that, in all three levels of impact energy, the computed statistic, $u$, is greater than the actual difference between the mean from the singleimpact tests and the mean from the successive-impact tests. The conclusion is that the hypothesis could be true, i.e., the two schemes of testing do not differ significantly.

\section{TEST RESULTS AND DISCUSSIONS}

\subsection{Deflection From Concentrated Static Load Prior to Impact} Loading

As described previously in section 2.3, two cycles of a static concentrated load of $4001 \mathrm{~b}$ were applied to the test panel prior to impact loading. Static deflections from the second cycle of loading, d4, are given in table 5. It is seen that deflection measurements are reasonably consistent even though there were noted a number of defects such as knotholes and bore holes in the plywoods used in the specimens. The ranges of the deflection for each group are depicted in figure 6. They varied from 0.017 in for group 2 specimens to 0.060 in for group 1 specimens. A large range of variation of data for the group 1 specimens is reasonable because of the use of A-D grade plywood. 
Average values of deflections show that a single layer subflooring of 5/8-in C-C plywood (group 2) deflected about 30 percent less than the subfloors which had 1/2-in C-D plywood with either 1/4-in A-A plywood or 1/4-in hardboard underlayment (groups $3 a$ and $4 a$, respectively). It is also apparent that the specimens which had discontinuous plywood subflooring (groups $3 \mathrm{~b}$ and $4 \mathrm{~b}$ ) showed approximately 1.5 times average deflections of the specimens which had continuous subflooring (groups $3 a$ and $4 a$ ). These results suggest that discontinuous edges in plywood subflooring may lead to excessive deflections.

\section{2 Impact Load Versus Floor Deflection from Concentrated Static Load}

Figures 7 through 12 show a plot of static deflections against impact energy for each group of specimens. The deflections plotted were measured under a concentrated load of $4001 \mathrm{~b}$ which was applied after each impact load. In the figures the ordinate is the potential energy of the bag and the abscissa is the deflection d 8 for each level of impact energy as described in section 2.3. It should be noted that the deflection $\mathrm{d} 4$ was used at zern impact energy. Thus, the offset from the origin of each figure indicates the amount of static deflection produced hy the second cycle of the 400-1b load applicd on a 5/8-in disc prior to impact loading. 
In each figure, the mean of the test points at each impact energy level is shown as an open circle. The means for each group of specimens are given in table 6. Because there were an inadequate number of test panels of the group 1 and $3 a$ specimens that sustained $600 \mathrm{ft}-1 \mathrm{~b}$ impact, the mean of these groups at this level was not determined. Most specimens of these groups were damage at this level of impact to such an extent that the deflection measurements were not possible. For ease of comparison, the average deflections given in table 6 are plotted in figure 13. The initial position of each curve indicates relative stiffness of the subflooring from the concentrated load of $4001 \mathrm{~b}$ applied prior to impact loading. Except for groups 1 and 3 b specimens, the static deflection from the 400-1b concentrated load increased linearly with increasing impact energy up to about $360 \mathrm{ft}$ 1b. Above this level the group 2 specimens began to show increasing deformation and the remaining three groups of specimens remained 1 inear up to $600 \mathrm{ft}-1 \mathrm{~b}$. It is interesting to note that there is little difference in the deflection resistance of two different kinds of underlayment used in this study; namely, 1/4-in A-A plywood or 1/4-in hardboard in combination with $1 / 2$-in C-D plywood. However, for subflooring which had a discontinuous edge under the impact area, the 1/4 - in hardboard underlayment showed greater deflection resistance than the $1 / 4$-in A-A plywood underlayment. 
A limiting level of impact energy could be obtained from figure 13 for a specific floor system provided that an acceptable deflection limit under the 400-1b concentrated load is established. At present, no such limit is found in the design specifications and standards used in the U.S. Based on results of tests conducted on 1/2-inch plywood subfloors with wood joists spaced at 16 inches O.C., the Canadian National Building Code - CAS 0152 [8] has a requirement for a maximum deflection limit for plywood subfloors. The deflection limit is $1 / 180$ of the span under a static concentrated load of 175 1b. An extrapolated value of the deflection of $1 / 2$-inch plywood subfloor supported at 16 inches o.c. under a 400-1b concentrated load is about 0.2 inch. If this value is taken as a maximum allowable deflection, figure 13 gives a limiting impact energy for group 1, group 4a, group $3 \mathrm{a}$ and group 2 specimens of about $60,300,360$ and $520 \mathrm{ft}$ 1b, respectively. Thus, if an expected maximum impact energy in dwelling is known, from a figure such as this, a practical choice of subflooring can be made for a limiting deflection. 


\section{Conclusions}

An investigation was conducted to determine the effect of impact load on the static deflection resistance of plywood subfloors nailed to wood joists. The following conclusions are based on the results of this investigation:

1. The plywood subfloors tested showed that deflection resistance under a concentrated load of $400 \mathrm{lb}$ decreased gradually as impact energy increased. Except for group 1 and group $3 b$ specimens, the increase in the deflection under the concentrated load with increase in the impact energy remained linear up to an impact energy level of $360 \mathrm{ft}-\mathrm{lb}$. For group $3 \mathrm{a}, 4 \mathrm{a}$ and $4 \mathrm{~b}$ specimens, the 1 inearity extended up to $600 \mathrm{ft}-1 \mathrm{~b}$. Grouns $3 \mathrm{a}$ and $4 \mathrm{a}$ specimens showed about the same rate of increase in deflection.

2. It was shown that a limiting impact energy for the floor could be obtained from a relationship between impact energy and static deflection under a concentrated load applied to the impacted area. However, an acceptable limit of the static deflection under the concentrated load needs to be established prior to obtaining such a limiting value of impact energy from the relationship. 
3. Static deflections from a static concentrated load of $400 \mathrm{1b}$ applied after impact loading indicate that increasing the thickness of plywood subflooring is more effective in increasing the deflection resistance of the subfloor than adding a layer of underlayment over the subfloor for about the same total thickness of subflooring. It was shown that the average deflection of a single layer 5/8-inch C-C plywood subfloor was about 30 percent less than that of the subfloor comprised of $1 / 2$-inch C-D plywood with 1/4-inch A-A plywood or 1/4-inch hardboard underlayment.

4. It was shown that for the specimens which had a layer of underlayment over the subflooring, the subflooring with discontinuous edge of plywood deflected approximately 1.5 times the subflooring with continuous sheet of plywood. 


\section{ACKNOWLEDGEMENTS}

The tests reported herein were performed by $\mathrm{Mr}$. James Seiler, engineering technician of the Structures Laboratory and Mr. Bruce Bean, a graduate student at University of New llampshire, who was a student summer worker in 1971. Mr. Bean also analyzed the test data. The author wishes to thank them for their contributions to this investigation.

Constructive criticisms of Dr. Robert Crist, Assistant Chief of Structures Section and careful review of the report by Dr. Norman F. Somes, Chief of the Structures Section are gratefully acknowledged. 
7. TABLES AND FIGURES 
TABLE 1. Description of Test Specimens

\begin{tabular}{|c|c|c|c|}
\hline \multicolumn{2}{|c|}{ Group } & Component of Specimens & No. of Tests \\
\hline 1 & $1 / 2$ in. A-D INT, Group 1* & 56 \\
\hline 2 & $\begin{array}{l}5 / 8 \text { in. Underlayment C-C } \\
\text { Plugged }\end{array}$ & 44 \\
\hline 3 & $\mathrm{a}$ & $\begin{array}{l}1 / 2 \text { in. C-D Plugged INT with } \\
1 / 4 \text { in. A-A Underlayment }\end{array}$ & 25 \\
\cline { 2 - 4 } & $\mathrm{b}+$ & $\begin{array}{l}1 / 2 \text { in. C-D Plugged INT with } \\
1 / 4 \text { in. A-A Underlayment }\end{array}$ & 28 \\
\hline 4 & $\begin{array}{l}1 / 2 \text { in. C-D Plugged INT with } \\
1 / 4 \text { in. Hardboard Underlayment } \\
1 / 2 \text { in. C-D Plugged INT Split } \\
\text { with 1/4 in. Hardboard Under - } \\
1 \text { ayment. }\end{array}$ & 28 \\
\hline
\end{tabular}

*For designations of plywood, refer to Appendix.

${ }^{+}$These specimens had splitted sheets of plywood panel thus providing aiscontinuous edge at the center of test panel. 
TABLE 2 Distribution of Tests

\begin{tabular}{|c|c|c|c|}
\hline Group & $\begin{array}{c}\text { Impact Test } \\
\text { Cnly }\end{array}$ & $\begin{array}{c}\text { Impact \& Static- } \\
\text { Load Test }\end{array}$ & $\begin{array}{c}\text { Tota1 No. } \\
\text { of Tests }\end{array}$ \\
\hline 1 & 46 & 10 & 56 \\
2 & 36 & 8 & 44 \\
$3 \mathrm{a}$ & 18 & 7 & 25 \\
$3 \mathrm{~b}$ & 22 & 6 & 28 \\
$4 \mathrm{a}$ & 30 & 6 & 36 \\
$4 \mathrm{~b}$ & 24 & 4 & 28 \\
\hline
\end{tabular}


TABLE 3 Single and Successive Drop Test Data for Group 2 Specimens

\begin{tabular}{|c|c|c|c|c|c|c|}
\hline \multirow{2}{*}{$\begin{array}{c}\text { No. of } \\
\text { Tests }\end{array}$} & \multicolumn{6}{|c|}{ Residual Deflection (in ) } \\
\cline { 2 - 7 } & A & $\mathrm{B}$ & $\mathrm{A}$ & $\mathrm{B}$ & $\mathrm{A}$ & $\mathrm{B}$ \\
\hline 1 & 0.003 & 0.008 & 0.011 & 0.004 & 0.012 & 0.014 \\
2 & 0.004 & 0.008 & 0.013 & 0.007 & 0.022 & 0.016 \\
3 & 0.005 & 0.010 & 0.018 & 0.009 & 0.026 & 0.018 \\
4 & 0.005 & & 0.020 & 0.018 & 0.027 & 0.022 \\
5 & 0.005 & & 0.036 & 0.024 & & 0.024 \\
6 & 0.011 & & 0.040 & 0.054 & & 0.031 \\
7 & 0.011 & & & & & 0.034 \\
8 & 0.012 & & & & & \\
9 & 0.016 & & & & & \\
10 & 0.019 & & & & & \\
11 & 0.029 & & & & & \\
\hline
\end{tabular}

$A=$ Single Drop Test on different test panel

$B=$ Successive Irop Test on the same test panel

* = $60 \mathrm{lb}$ bag $\mathrm{x}$ height of Drop

Note: Data have been rearranged for convenience of comparison in increasing order of residual deflection. 


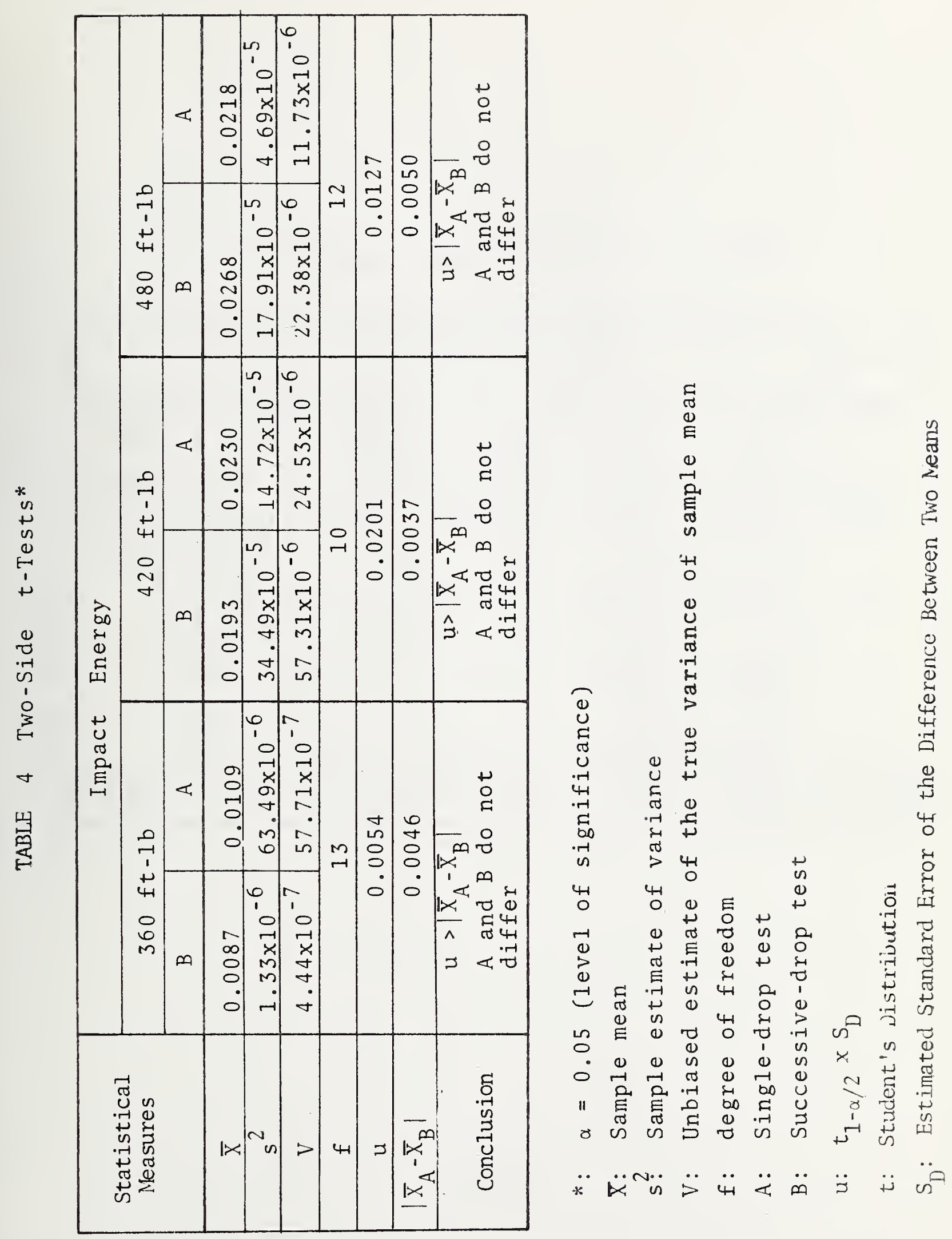


TABLE 5 Initial Static Deflection Under $400 \mathrm{lb}$

\begin{tabular}{|c|c|c|c|c|c|c|}
\hline \multirow{2}{*}{$\begin{array}{c}\text { No. of } \\
\text { Test }\end{array}$} & \multicolumn{6}{|c|}{ Static Deflection (in) } \\
\hline & Group 1 & Group 2 & Group 3a & Group 3b & Group $4 a$ & Group 4b \\
\hline 1 & 0.162 & 0.089 & 0.154 & 0.248 & 0.151 & 0.210 \\
\hline 2 & 0.167 & 0.110 & 0.158 & 0.251 & 0.150 & 0.217 \\
\hline 3 & 0.170 & 0.100 & 0.153 & 0.242 & 0.151 & 0.201 \\
\hline 4 & 0.191 & 0.102 & 0.158 & 0.234 & 0.164 & 0.205 \\
\hline 5 & 0.222 & 0.102 & 0.157 & 0.205 & 0.149 & \\
\hline 6 & 0.193 & 0.099 & 0.154 & 0.200 & 0.129 & \\
\hline 7 & 0.192 & 0.109 & 0.139 & & & \\
\hline 8 & 0.168 & 0.117 & & & & \\
\hline 9 & 0.199 & 0.114 & & & & \\
\hline 10 & 0.200 & 0.108 & & & & \\
\hline Avg. & 0.186 & 0.104 & 0.153 & 0.230 & 0.149 & 0.208 \\
\hline
\end{tabular}


TABLE 6 Mean Deflections Under 400-1b Static Load

\begin{tabular}{|c|c|c|c|c|c|c|}
\hline \multirow{2}{*}{$\begin{array}{c}\text { Impact Energy } \\
(\mathrm{ft}-1 \mathrm{~b})\end{array}$} & \multicolumn{7}{|c|}{ Static Deflection (in.) } \\
\cline { 2 - 7 } & Group 1 & Group 2 & Group 3a & Group 3b & Group 4a & Group 4b \\
\hline 0 & 0.186 & 0.104 & 0.153 & 0.230 & 0.149 & 0.208 \\
120 & 0.193 & & & & & \\
180 & 0.212 & 0.111 & 0.161 & 0.254 & 0.161 & 0.227 \\
240 & 0.240 & & & & & \\
300 & 0.304 & 0.117 & 0.174 & 0.294 & 0.186 & 0.262 \\
360 & 0.331 & & & & & \\
480 & 0.363 & 0.132 & 0.198 & 0.363 & 0.210 & 0.244 \\
600 & 0.442 & 0.170 & 0.222 & 0.416 & 0.228 & 0.318 \\
\hline
\end{tabular}



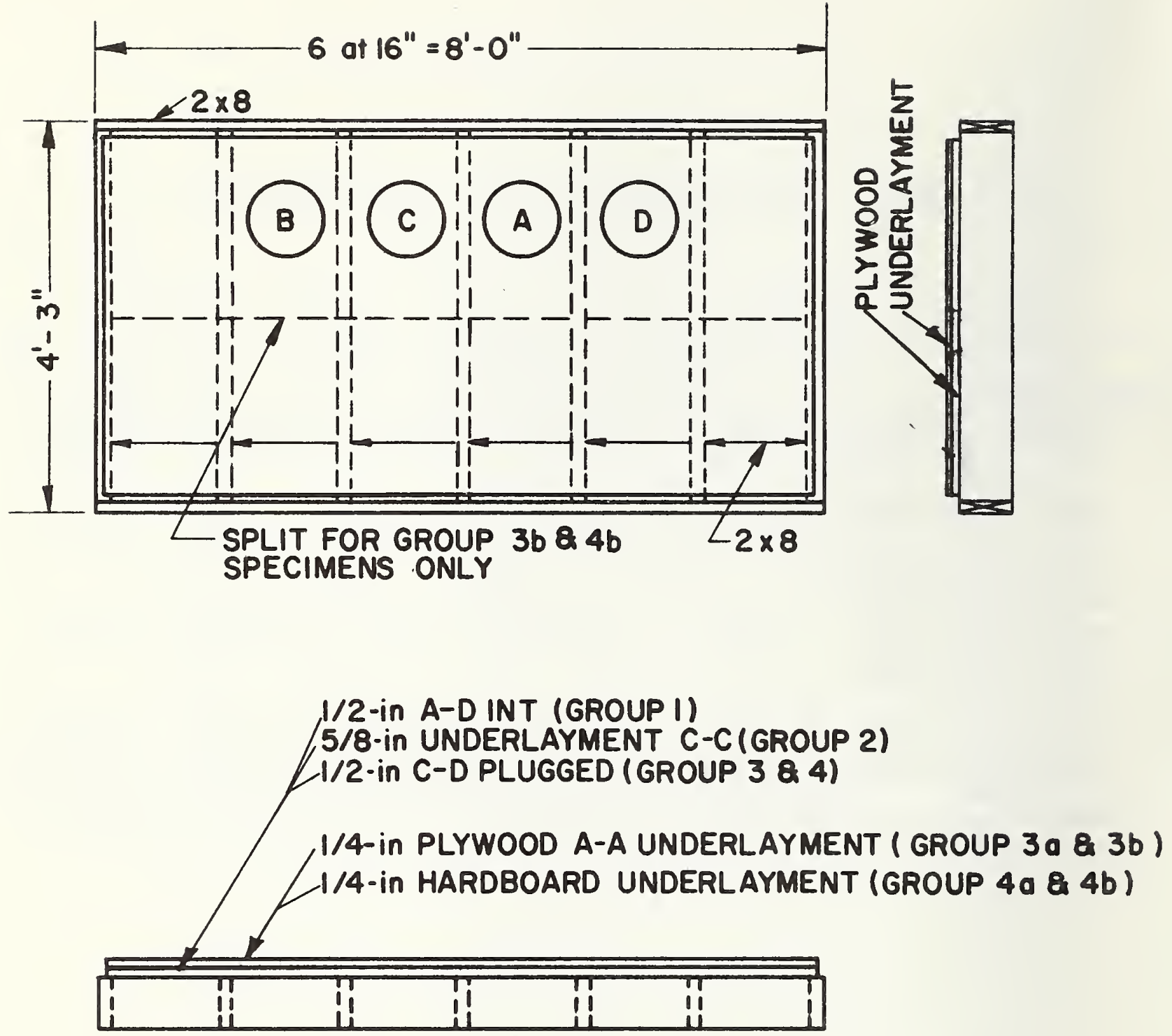

FIGURE 1 Test Specimen 


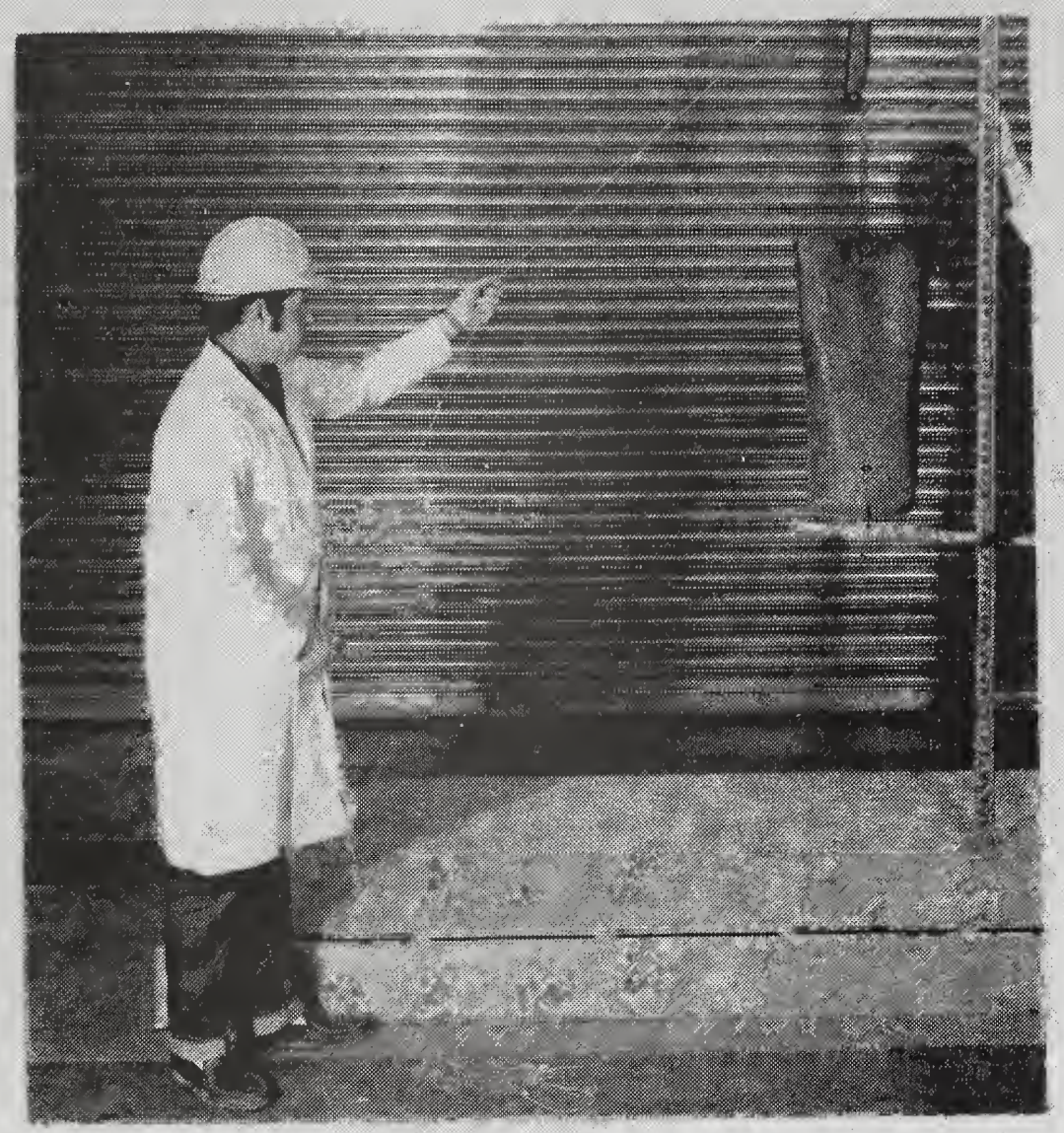

FGURE 2 Impact Test Setup 


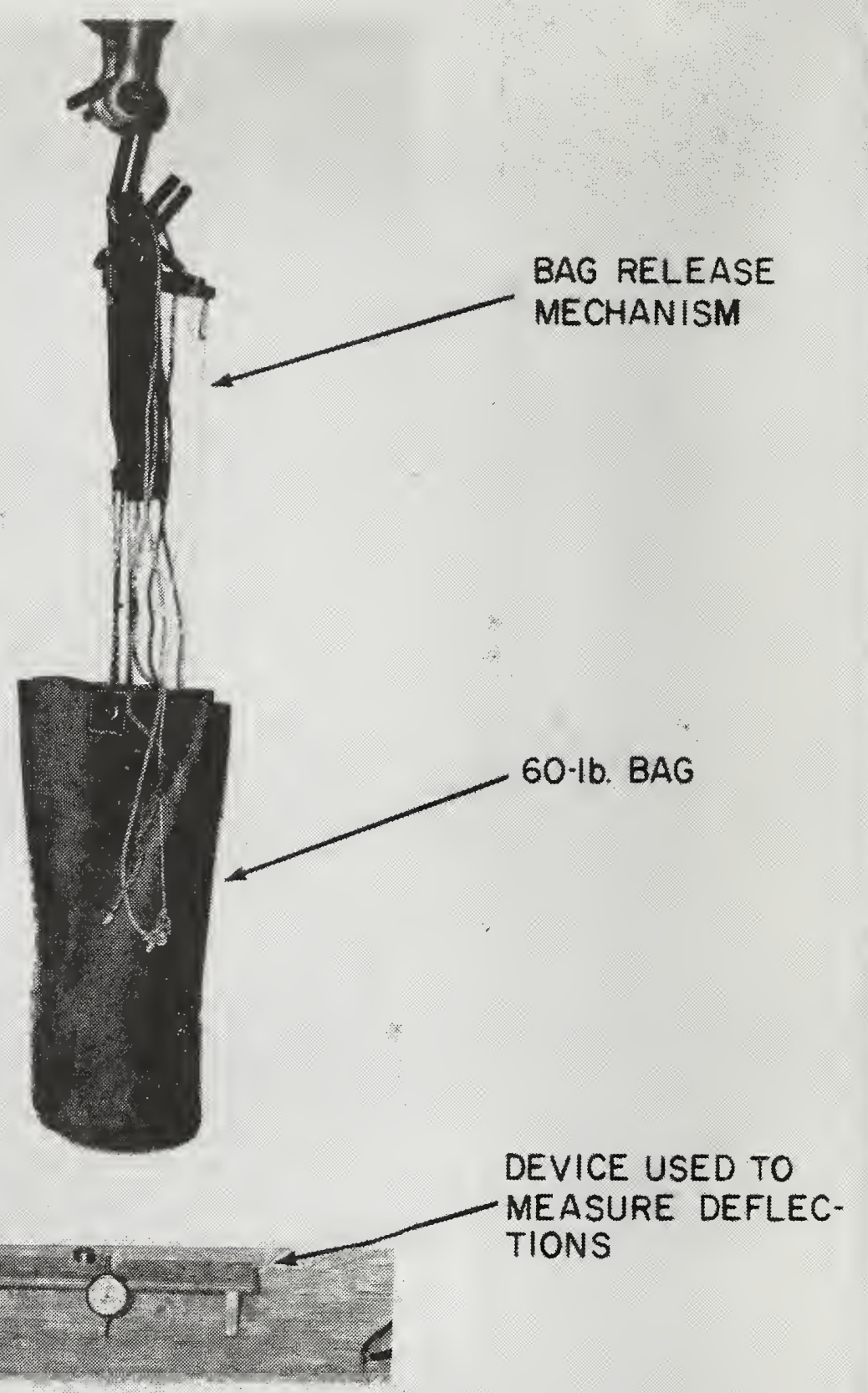

FIGURE 3 60-lb Sandbag,

Bag Release Mechanism and

Device Used to Measure Deflections 


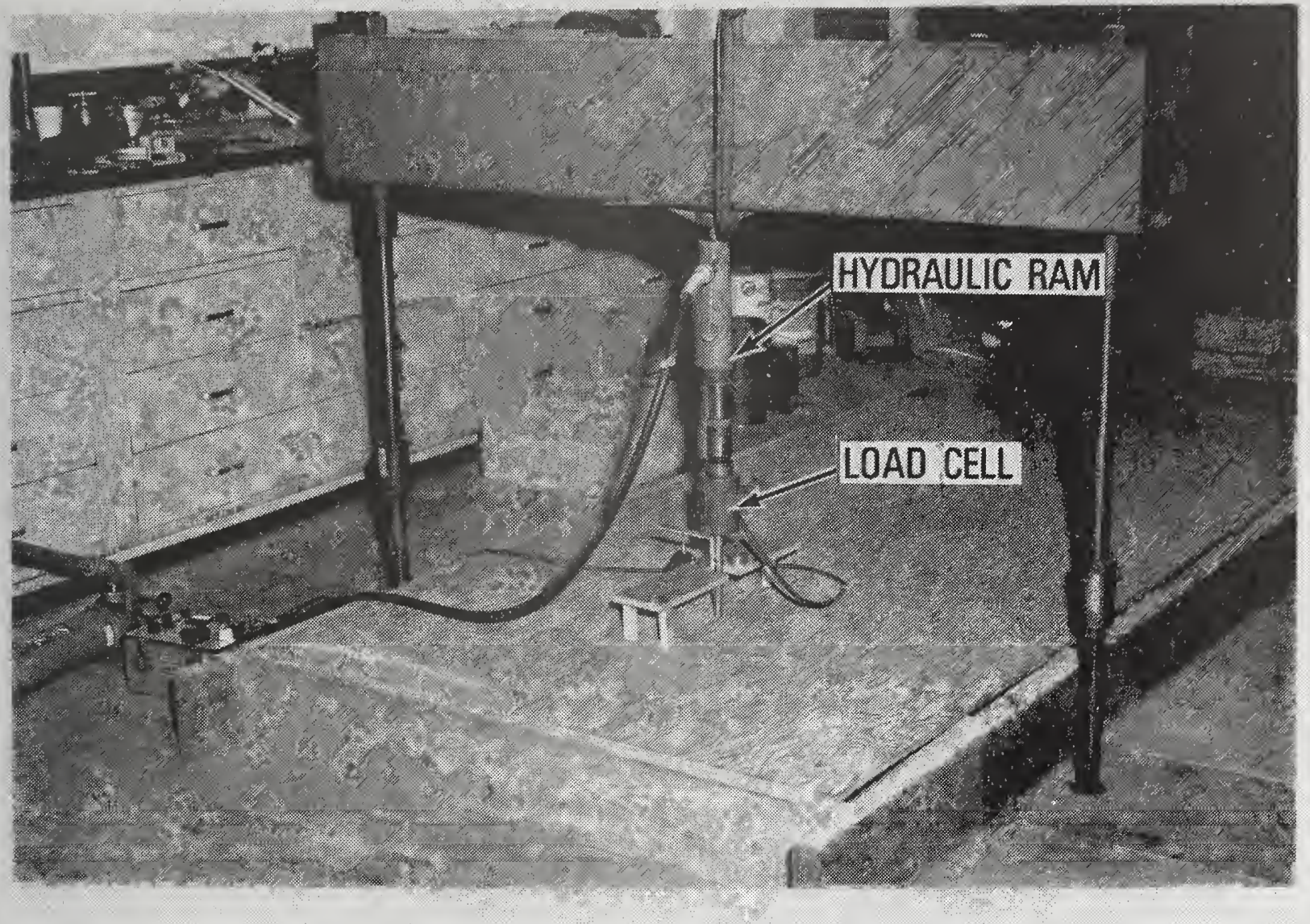

FGURE 4 Concentrated Load Test Setup 


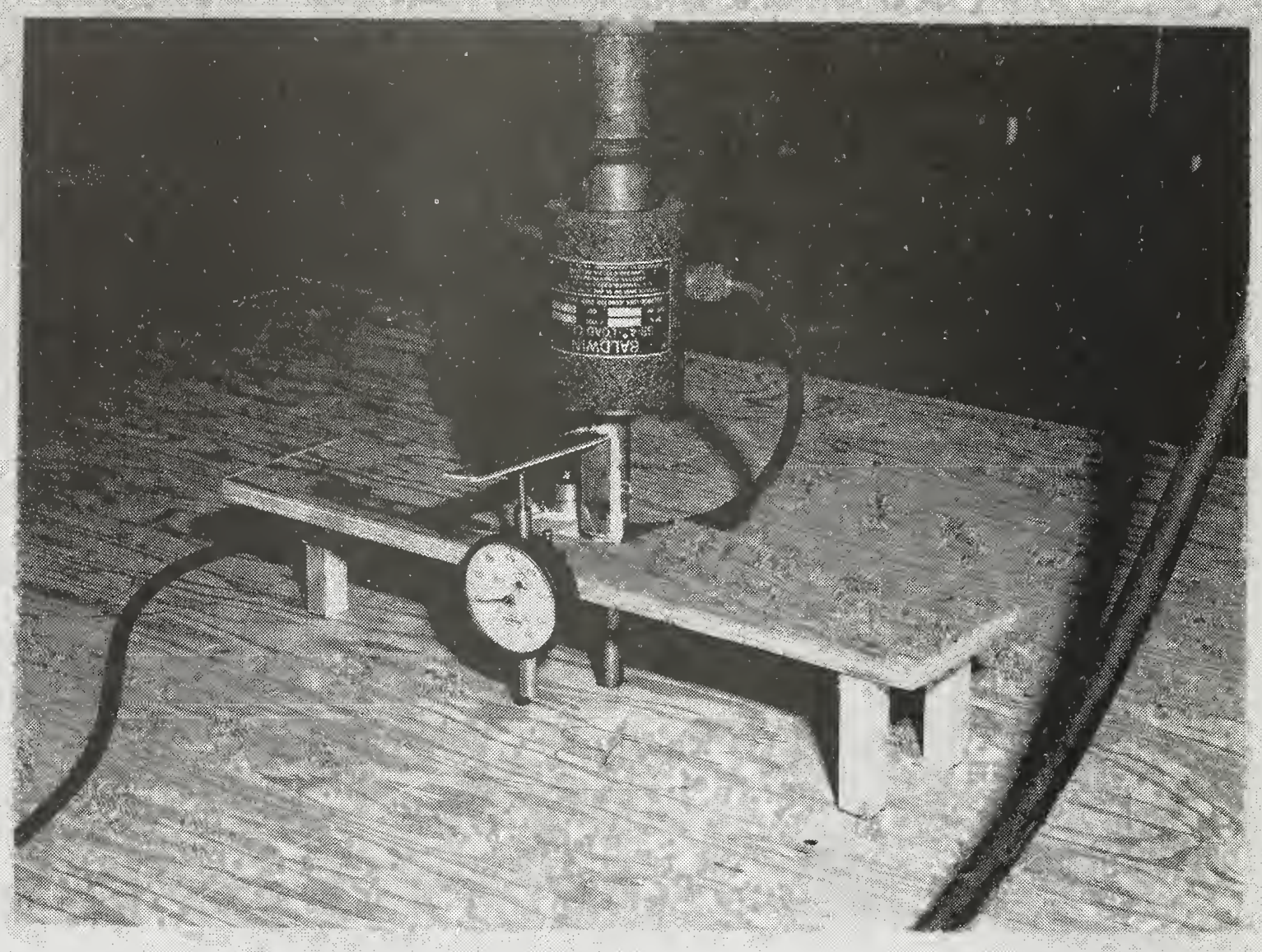

FIGURE 5 Rig Used for Deflection Measurements in Static Tests 


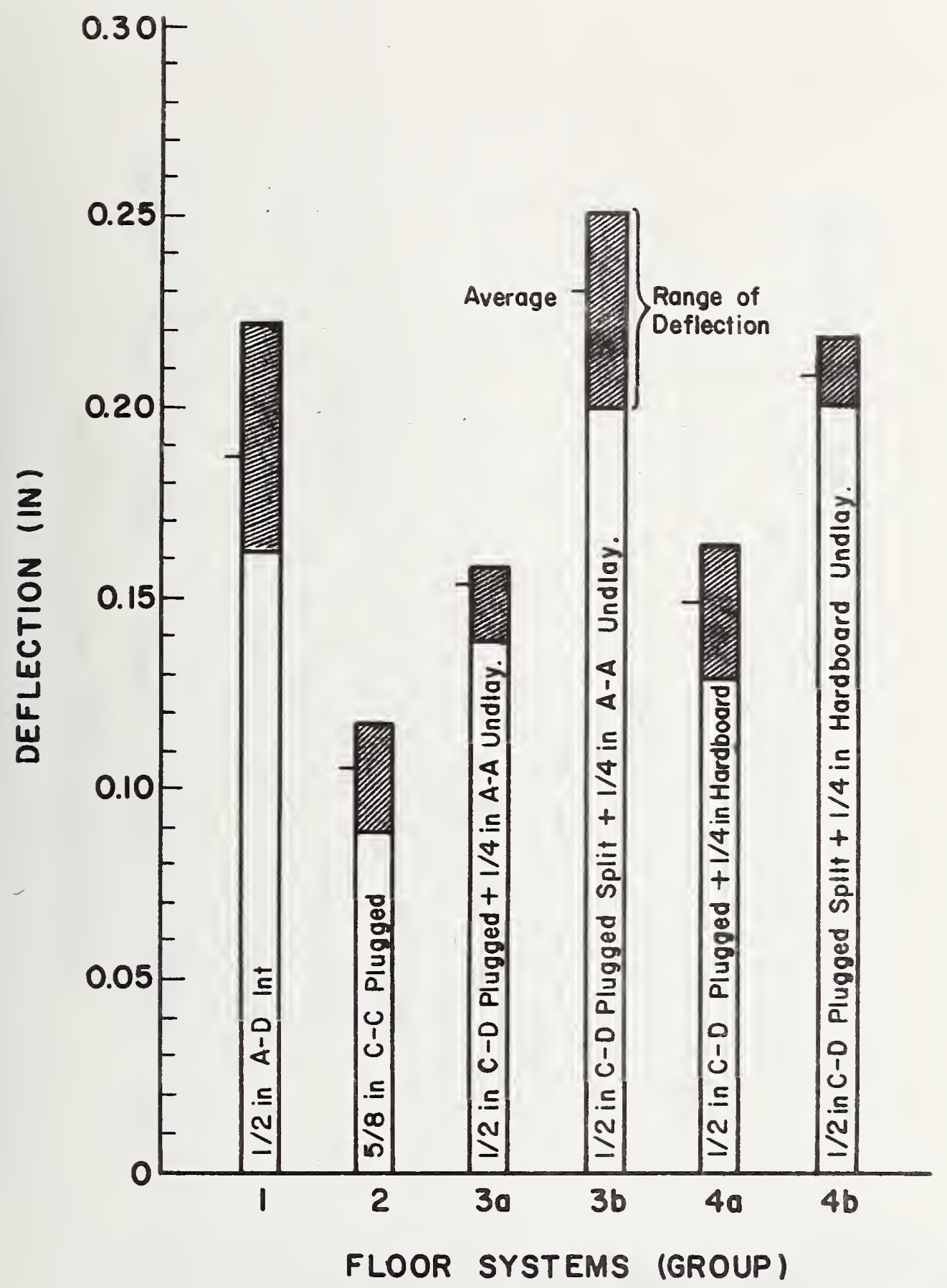

FIGURE 6 Range of Static Deflection Measured Prior to Impact Loading 


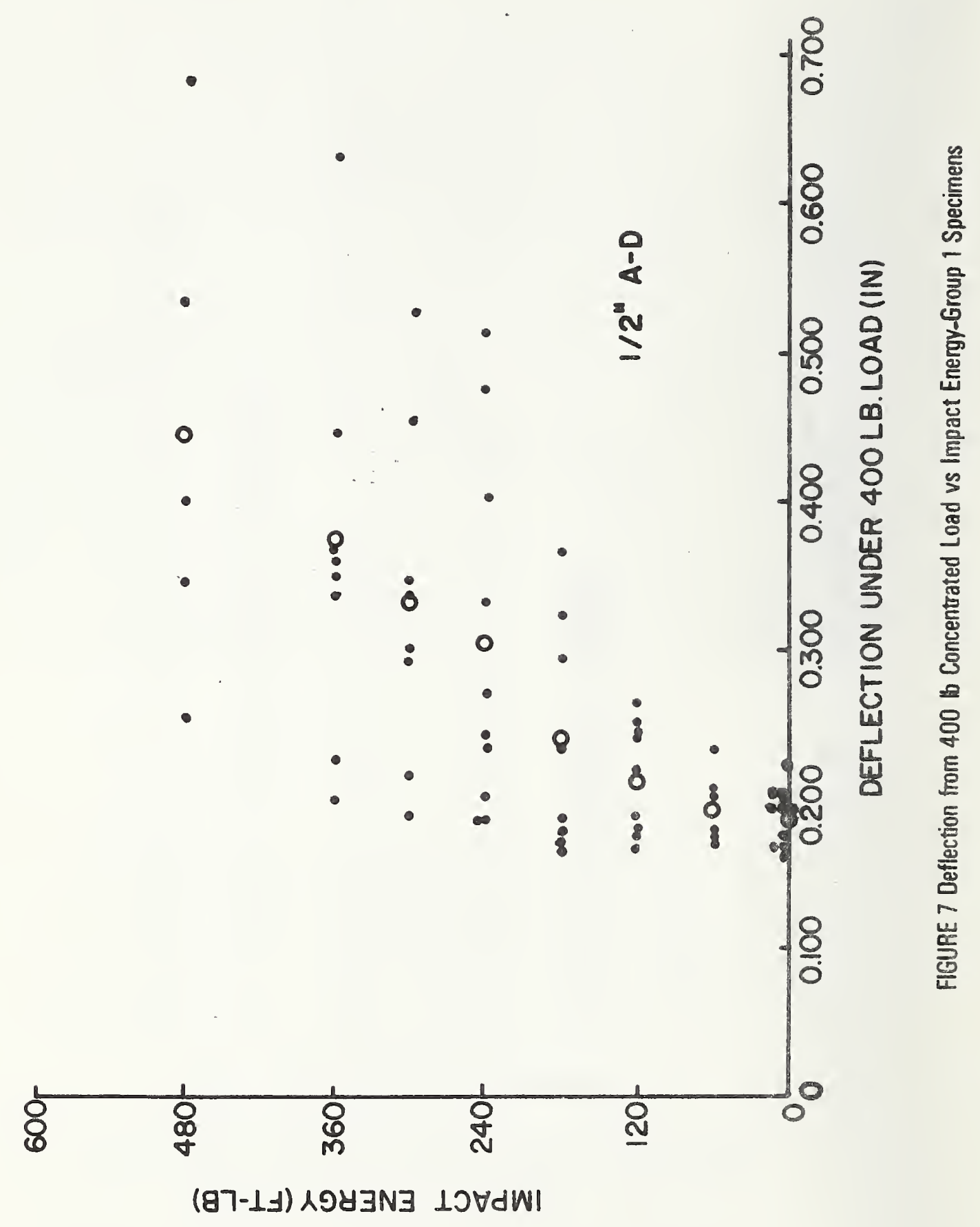




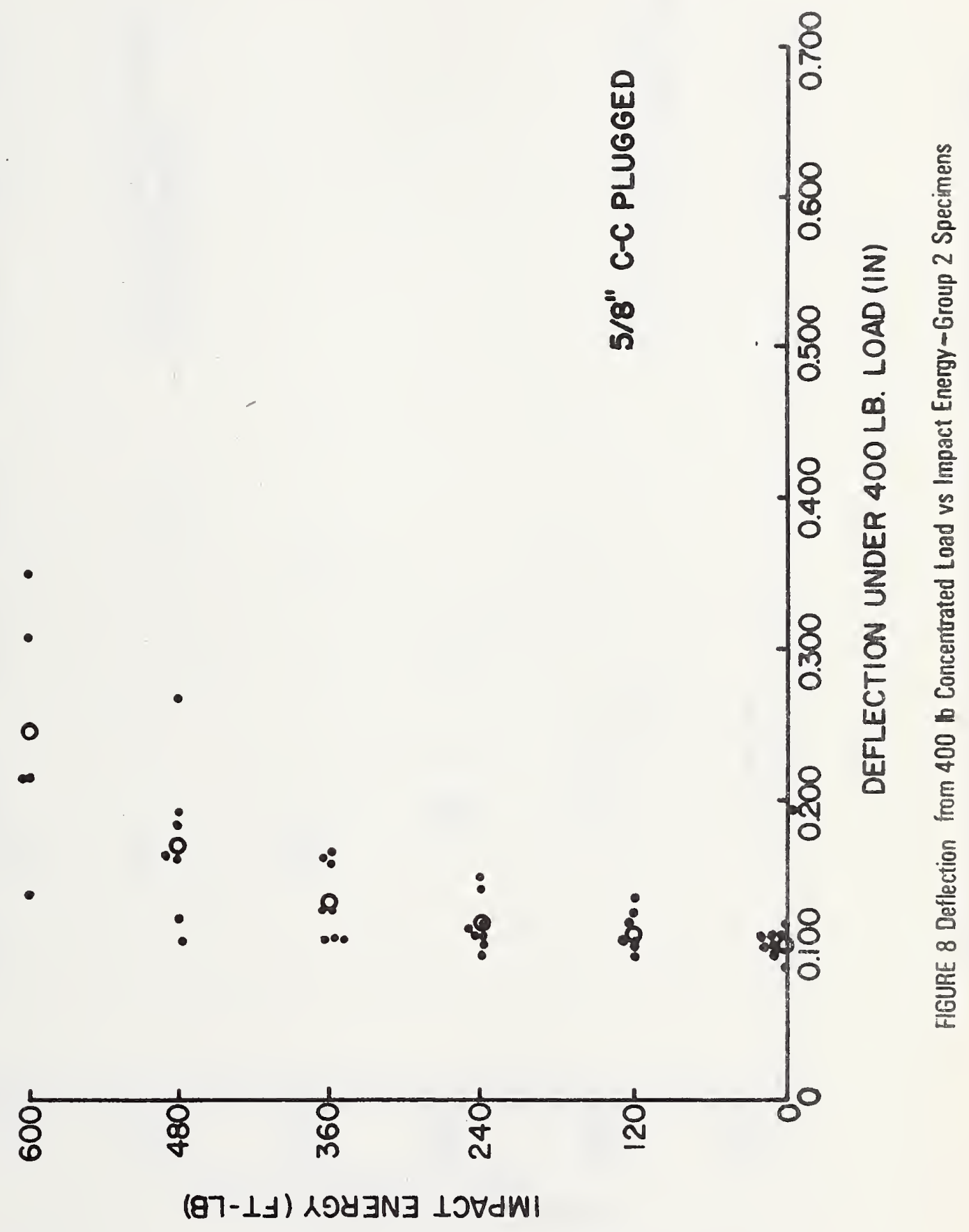




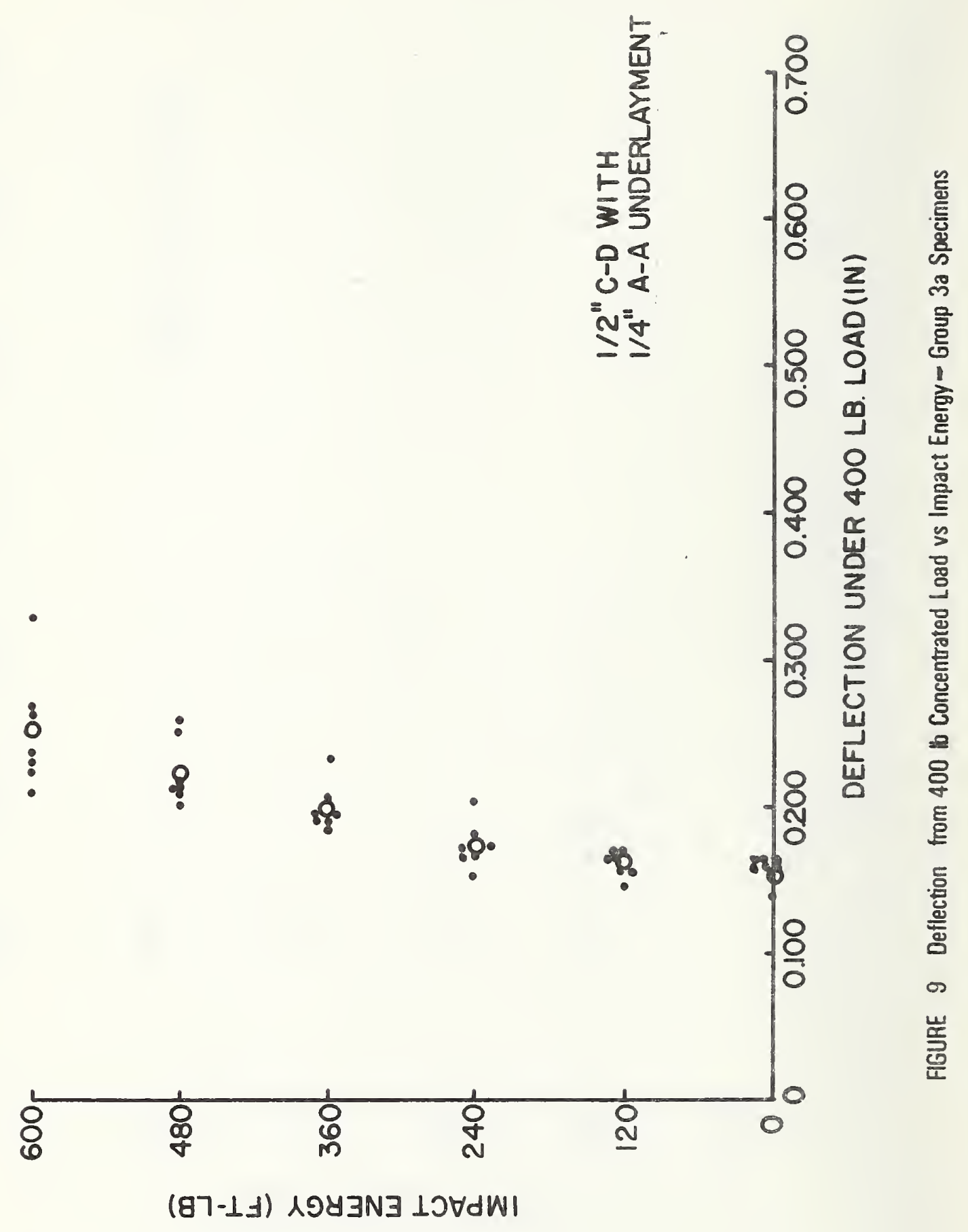




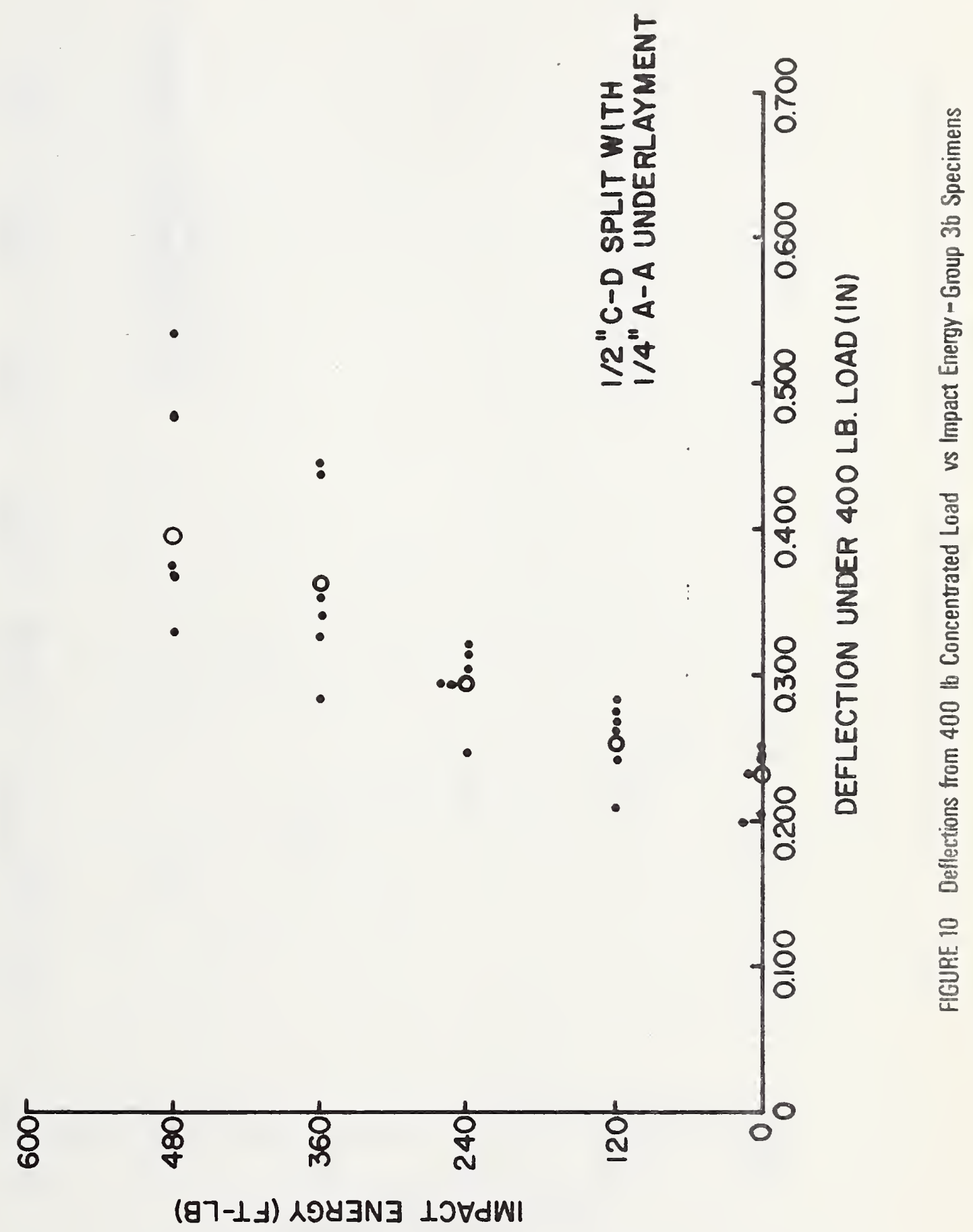




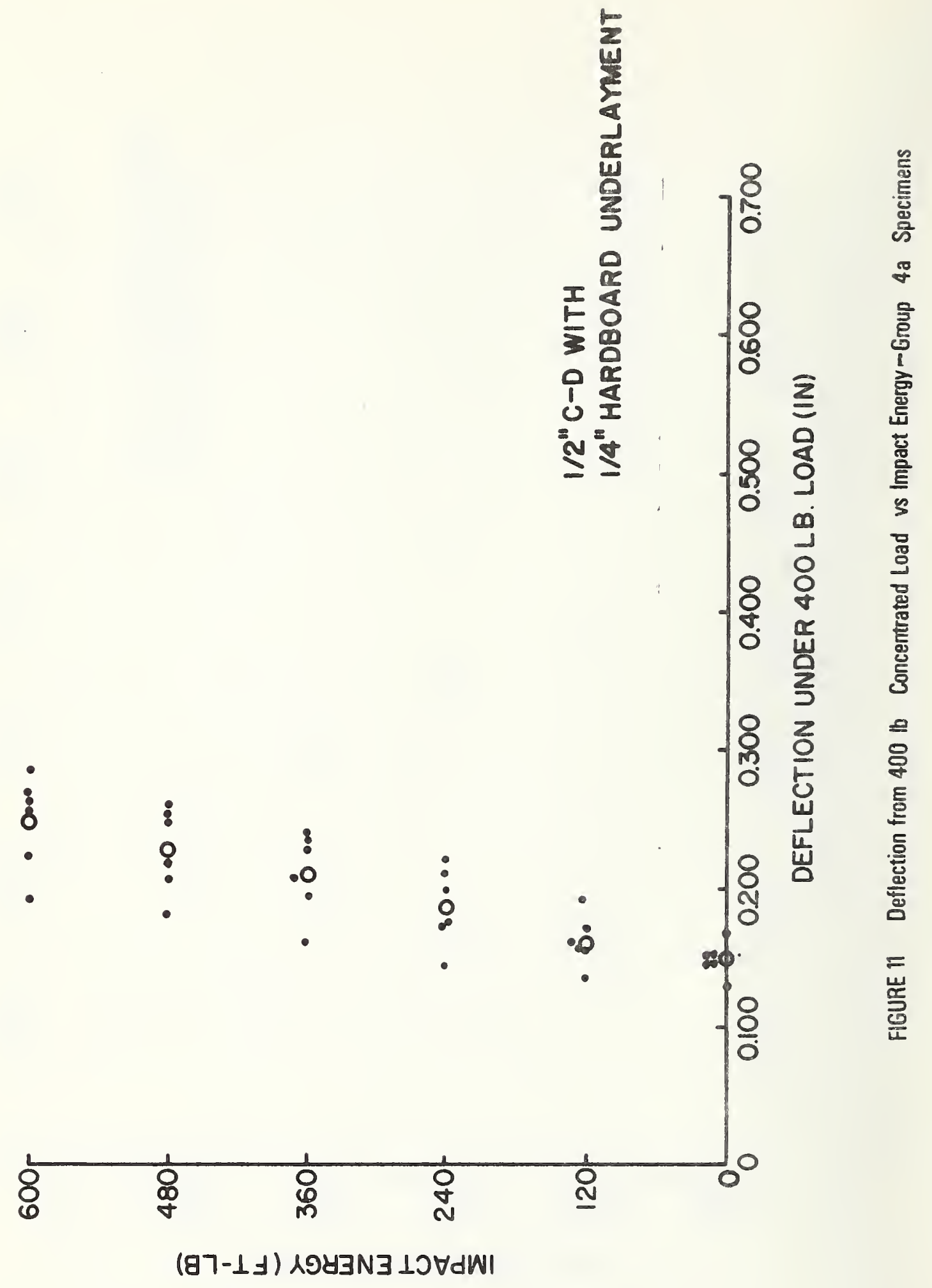




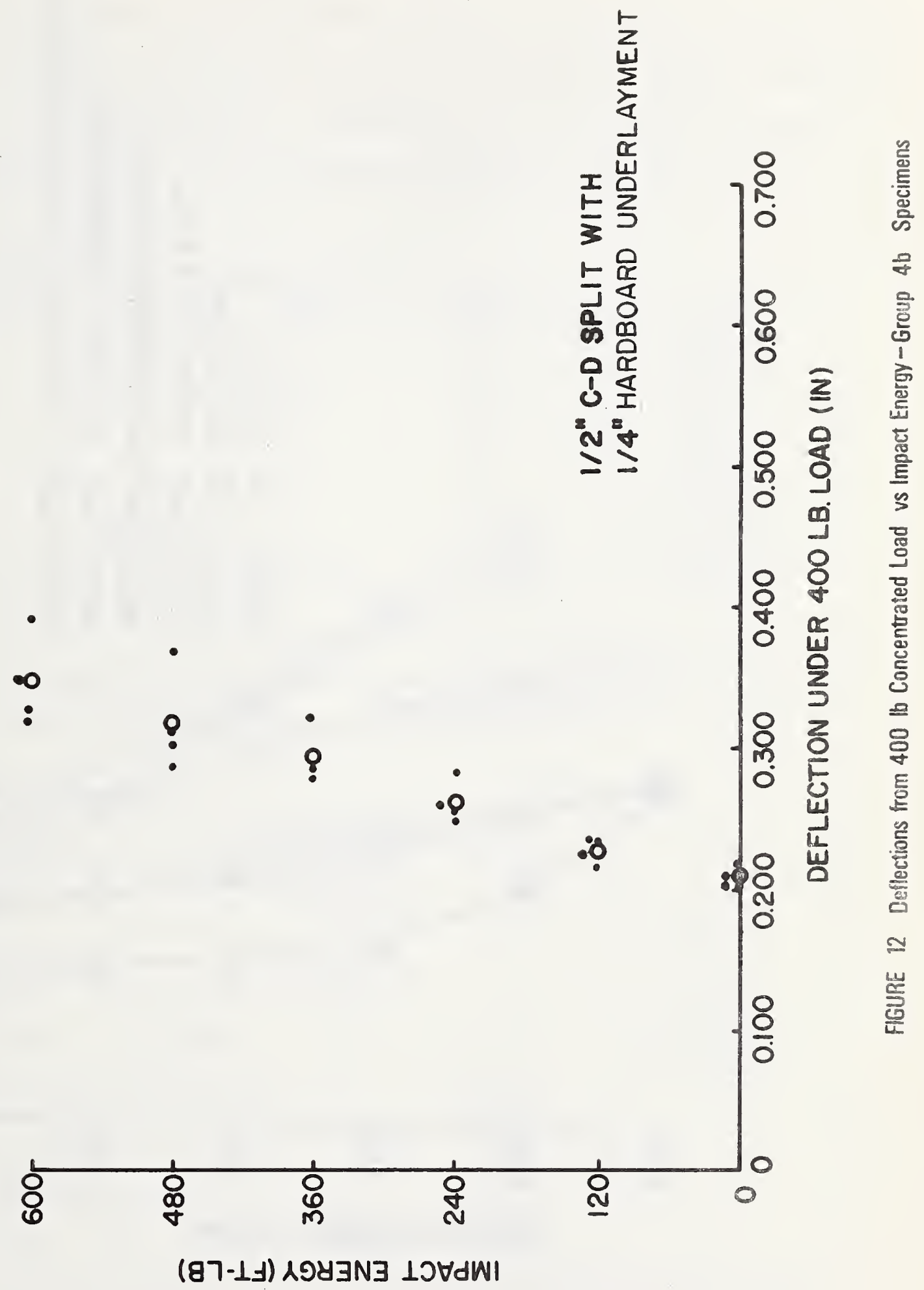




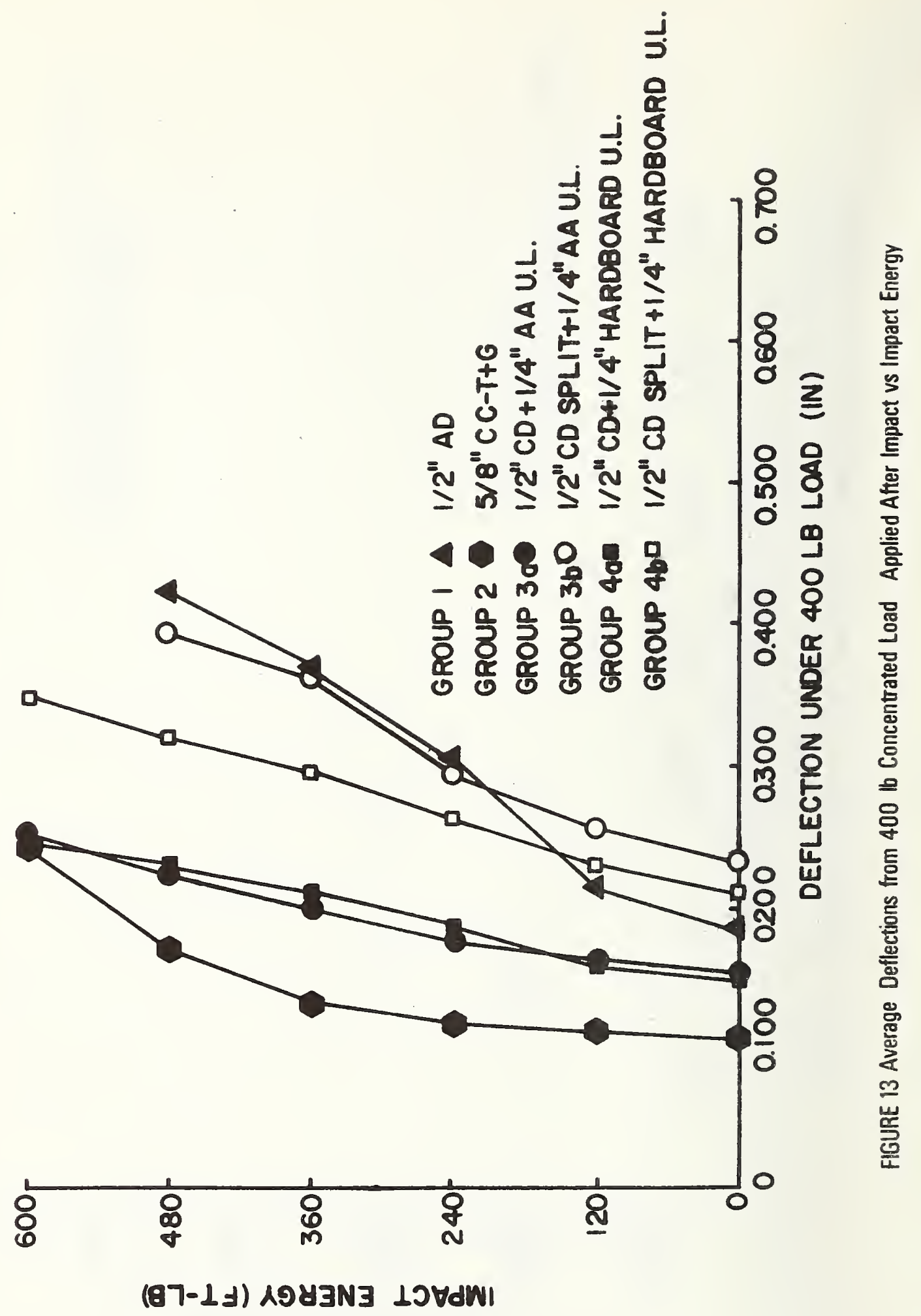


For reference, the following tables and grade descriptions for veneers are reproduced from NBS Voluntary Product Standard PS 1-66 "Softwood Plywood, Construction and Industrial" and from a publication of the American Plywood Association.

Interior Type Grades

\begin{tabular}{|c|c|c|c|c|}
\hline $\begin{array}{l}\text { Panel } \\
\text { Grade Designations }\end{array}$ & Face & $\begin{array}{c}\text { Minimum Veneer Quality } \\
\text { Back }\end{array}$ & Inner Plys & Surface \\
\hline $\begin{array}{c}\text { N-N. } \\
\text { N-A' } \\
\text { N-B' } \\
\text { N-D' } \\
\text { A-A } \\
\text { A-B } \\
\text { A-D } \\
\text { B-B } \\
\text { B-D } \\
\text { Underlayment } \\
\text { C.D (Plugged) } \\
\text { STRUCTURAL } \\
\text { STANDARD } \\
\text { STANDARD WiITH } \\
\text { EXTERIOR GLUE } \\
\text { (SEe Para. 3.4.5) }\end{array}$ & $\begin{array}{c}\text { N } \\
N \\
N \\
N \\
A \\
A \\
A \\
B \\
B \\
C \text { (Plugged) } \\
\text { C (Plugged) } \\
\text { C }\end{array}$ & $\begin{array}{c}\text { N } \\
\text { A } \\
\text { B } \\
\text { D } \\
\text { A } \\
\text { B } \\
\text { D } \\
\text { B } \\
\text { D } \\
\text { D } \\
\text { D } \\
\text { See Paragraph } 3.4 .4 \\
\text { D }\end{array}$ & $\begin{array}{l}C \\
C \\
C \\
D \\
D \\
D \\
D \\
D \\
D \\
C^{3} \& D \\
D \\
D \\
D\end{array}$ & $\begin{array}{c}\text { Sanded } 2 \text { sides } \\
\text { Sanded } 2 \text { sides } \\
\text { Sanded } 2 \text { sides } \\
\text { Sanded } 2 \text { sides } \\
\text { Sanded } 2 \text { sides } \\
\text { Sanded } 2 \text { sides } \\
\text { Sanded } 2 \text { sides } \\
\text { Sanded } 2 \text { sides } \\
\text { Sanded } 2 \text { sides } \\
\text { Sanded or touch-sanded } \\
\text { as specified } \\
\text { Unsanded or touch- } \\
\text { sanded as specified } \\
\text { Unsanded grade: } \\
\text { Unsanded grade* } \\
\text { Unsanded grade" }\end{array}$ \\
\hline
\end{tabular}

(1) Natural finish items iniended primarly for cabinet work. Avallable Benerally only in 3/4" thickness and only from certasn mills.

(2) Natural finish item. intended primarily for panelirg and wainscot. ing. Available genera:iy only in $1 / 4^{\circ}$ thickness and only from certain mills.
(3) Veneer immediately adjacent to face shall be $\mathrm{C}$ or better.

(4) Panels shall not be sanded. touch-sanded. or thickness sized by any mechanicsl means.

\section{Exterior Type Grades ${ }^{2}$}

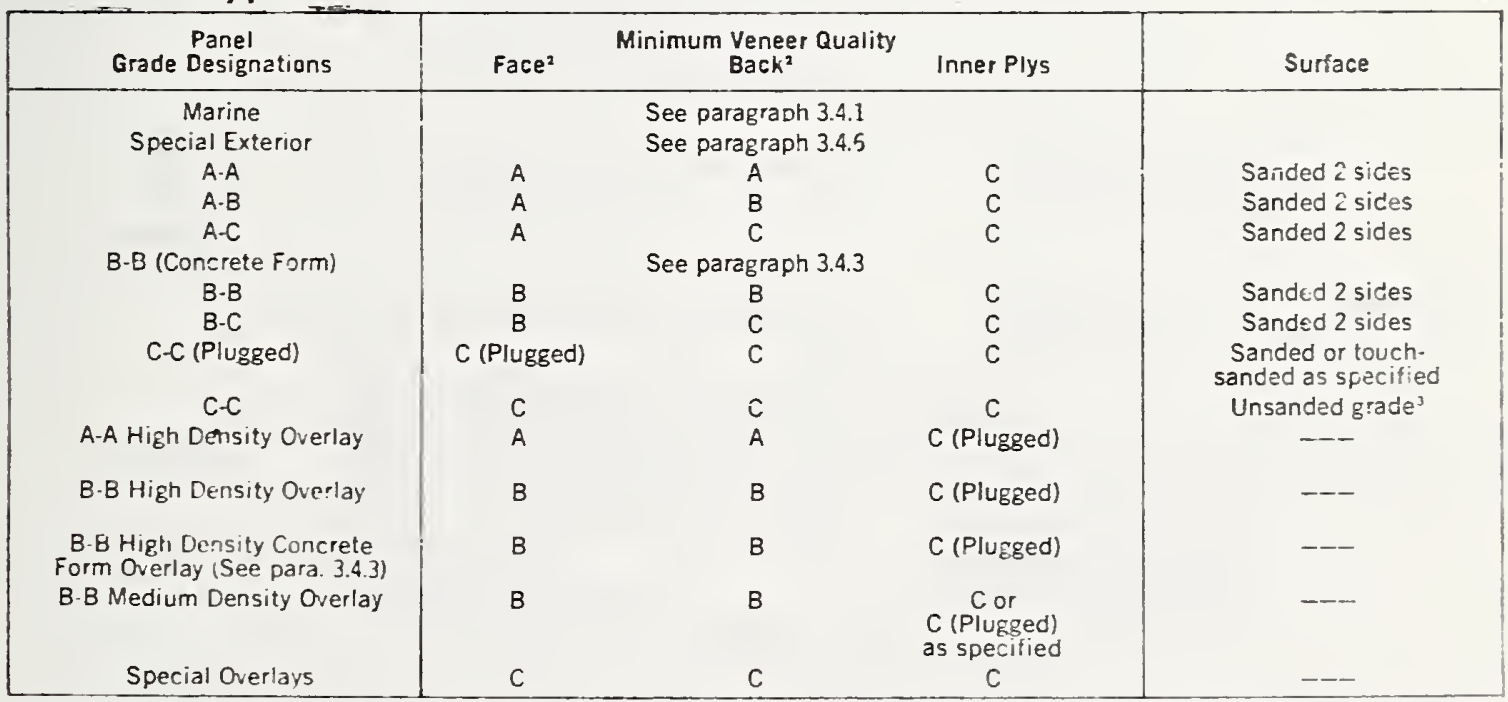

(1) Avaliahie also in STPUCTURAL 1 classification as provided in paragraph 3.4 .4 (2) For overlaid piywood, the grade cesirnation for tace and oack
refers to the veneer direclly underlying the surtace. All overlaid plywood is overiaid on two sides unless otherwise snecilied when only. One side is surfaced, the exposed back srall be $C$ or bi. er.

(3) Parels shall not be sanded. touch-sanded or thickness sized by eny mecranical means. 


\section{Classification of Species}

\begin{tabular}{lll} 
Group 1 & \multicolumn{2}{c}{ Group 2 } \\
\hline Birch & Cedar, Port Orford & Maple, Black \\
Yellow & Douglas Fir 2 & Meranti \\
Sweet & Fir California Red & Mengkulang \\
Douglas Fir 1 & Pine \\
Larch, Western & Grand & Pond \\
Maple, Sugar & Noble & Red \\
Pine, Caribbean & Pacific Silver & Western white \\
Pine, Southern & White & Spruce, Sitka \\
Loblolly & Hemlock, Western & Sweet Gum \\
Longleaf & Lauan & Tamarack \\
Shortleaf & Red & \\
Slash & Tangile & \\
Tanoak & White & \\
& Almon & \\
& Bagtikan &
\end{tabular}

Group 3

Alder, Red

Cedar

Alaska

Pine

Jack

Lodgepole

Ponderosa

Spruce

Redwood

Spruce

Black

Red

White
Group 4

Aspen

Bigtooth

Quaking

Birch, Paper

Cedar

Incense

Western Red

Fir, Subalpine

Hemlock, Eastern

Pine

Sugar

Eastern White

* Poplar, Western

Spruce, Engelmann 


\section{Veneer grades used in plywood}

\begin{tabular}{|c|c|c|}
\hline Veneer Grade & \multicolumn{2}{|c|}{ Limiting Characteristics } \\
\hline $\begin{array}{l}\text { Intended for } \\
\text { Natural Finish }\end{array}$ & $\begin{array}{l}\text { Presents smooth surface. } \\
\text { Veneer shall be all heartwood or all sapwood free from } \\
\text { knots, knotholes, open splits, pitch pockets, other open } \\
\text { cefects, and stain but may contain pitch streaks } \\
\text { averaging not more than } 3 / 8^{\prime \prime} \text { wide blendin: with color } \\
\text { of wood. } \\
\text { if joined, not more than two pieces in } 48^{\prime \prime} \text { width; not } \\
\text { more thar three pieces in wider panels. Joints parallel } \\
\text { to panel edges and well-matiched for color and grain- } \\
\text { Repairs shall be neatly made, well-matched for color } \\
\text { and grain, and limited to a total of six in number in } \\
\text { any } 4^{\prime} \times 8^{\prime} \text { sheet. }\end{array}$ & $\begin{array}{l}\text { - Maximum of three "router" patches not exceeding } \\
3 / 4^{\prime \prime} \times 3-1 / 2^{\prime \prime} \text { admitted. No overlapping. } \\
\text { - Shims admitted not exceeding } 12 \text { " in length but may } \\
\text { occur only at ends of panel. (Examp'es of permissible } \\
\text { combinations: } 3 \text { router patches and } 3 \text { shims, } 2 \text { router } \\
\text { patches and } 4 \text { shims, } 1 \text { router patch and } 5 \text { shims, or } \\
6 \text { shims). } \\
\text { Suitable synthetic fillers may be used to fill } 132^{\prime \prime} \text { wide } \\
\text { checks, splits up to } 1 / 16^{\prime \prime} \times 2^{\prime \prime} \text { and chipped areas or } \\
\text { other openings not exceeding } 1 / 8^{\prime \prime} \times 1 / 4 " \text {. }\end{array}$ \\
\hline & 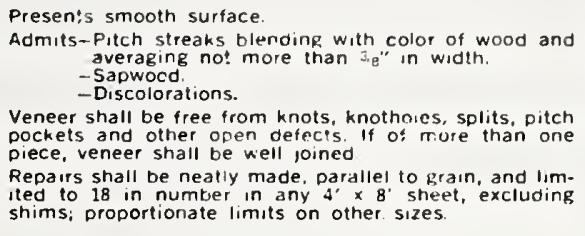 & 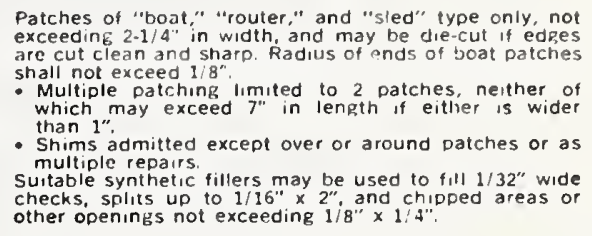 \\
\hline & $\begin{array}{l}\text { Presents solid surface. } \\
\text { Admits-Knots up to } 1^{\prime \prime} \text { across the grain if both sound } \\
\text { and tight. } \\
\text { - Pitch streaks averaging not more than } 1^{\prime \prime} \text { in } \\
\text { width. } \\
\text { - Discolorations. } \\
\text { - Slightly rough but nor torn grain, minor sanding } \\
\text { and patching defects, including sander skips } \\
\text { not exceeding } 5^{\circ} \text { of of panel area. } \\
\text { veneer shall be free from open derects excect for splits } \\
\text { not wider than } 1 \text { 32", vertical holes up to } 1 \text { is" in } \\
\text { diameter if not exceeding an average ol one per square } \\
\text { foot in number, and horizontal or surface tunneis up to } \\
1 / 16^{\prime \prime} \text { in width and } 1^{\prime \prime} \text { in length not exceeding } 12 \text { in num- }\end{array}$ & 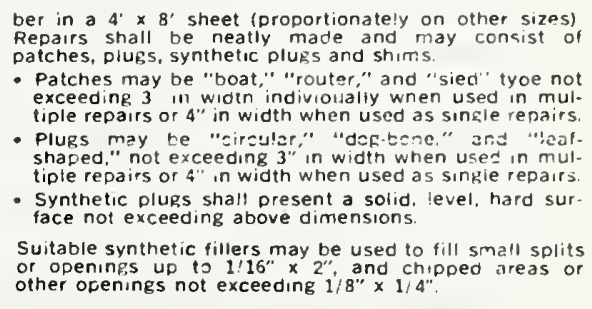 \\
\hline & 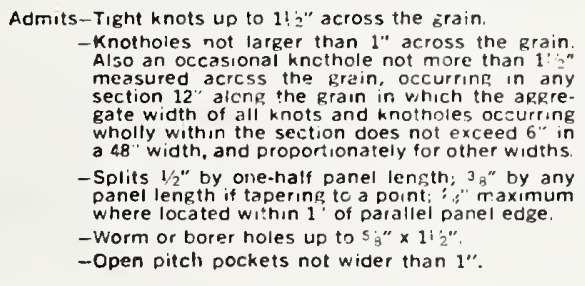 & $\begin{array}{l}\text { Repairs shall be neatly made and may corisist of patches, } \\
\text { plugs, and synthetic plugs. } \\
\text { Patches ("boat," including die-cut) not exceeding 3" in } \\
\text { width individually when used in multiple repairs or } 4 \text { " } \\
\text { in width when used as single repairs. Flugs may be } \\
\text { circular, "dog-bone" and leaf-shaped. Synthetic plugs } \\
\text { shall present a solid, level, hard surface not exceeding } \\
\text { above dimensions. }\end{array}$ \\
\hline (nlugged) & 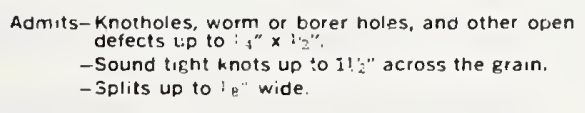 & $\begin{array}{l}\text { - Ruptured and torn grain. } \\
\text { - Pitch pockets if solid and tight. } \\
\text {-Plugs, patches and shims. }\end{array}$ \\
\hline & 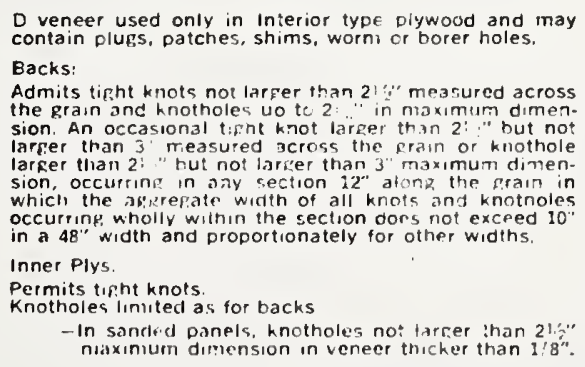 & 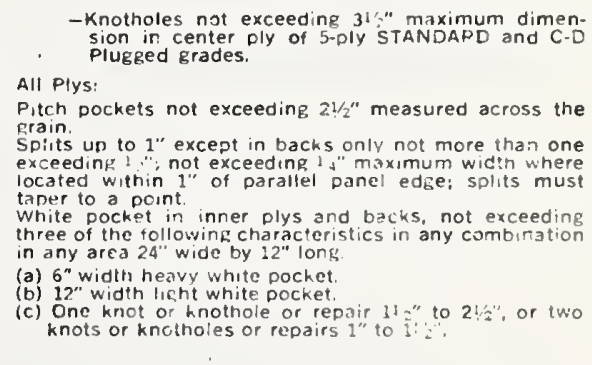 \\
\hline
\end{tabular}


1. National Bureau of Standards, U.S. Department of Conmerce, "Guide Criteria for the Evaluation of Operation BREAKTHROUGH Housing Systems."

Vol. 1. Multifamily High Rise - Accession No. PB-212055

Vo1. 2. Multifamily Low Rise - Accession No. PB 212056

Vol. 3. Single Family Attached - Accession No. PB 212057

Vol. 4. Single Family Detached - Accession No. PB-212058

National Technical Information Service, U.S. Department of Commerce, Springfield, Va. 22151.

2. Boyd J. D., "Minimum Strength and Stiffness Necessary for Wooden Floors in Houses," Paper No. 34 CSIRO, Division of Forest Product Technology, Melbourne, Australia, 1964.

3. U. S. Department of Commerce, "Product Standards PS 1-66--Softwood Plywood, Construction and Industrial," Washington, D. C., November 1966.

4. General Service Administration, "Federa1 Specification, LLL-B-810a Building Board, (Hardboard) Hard Pressed, Vegetable Fiber," Washington, D. C., July 1965.

5. Federal Housing Administration, "Minimum Property Standards for One and Two Living Units,: Washington, D. C., November 1966, as subsequently amended. 
6. ASIM Designation 1:72-68, "itiandard Methods of Conducting Strength Tests of Panels for Building Construction," American Society for Testing Materials, Philadelphia Pennsylvania, 1971.

7. Natrella, M. G., "Experimental Statistics," National Bureau of Standards Handbook 91, Washington, D. C., August 1963.

8. "Performance of Construction Plywood," CSA Standard 0159, Ottawa, Canada, 1964. 
FORM NBS-114A (1.71)

\begin{tabular}{|c|c|c|c|}
\hline $\begin{array}{l}\text { U.S. DEPT. OF COMM. } \\
\text { BIBLIOGRAPHIC DATA } \\
\text { SHEET }\end{array}$ & $\begin{array}{l}\text { 1. PUBLICATION OR REPORT NO. } \\
\text { NBSIR 73-187 }\end{array}$ & $\begin{array}{l}\text { 2. Gov't Accession } \\
\text { No. }\end{array}$ & 3. Recipient's Accession No. \\
\hline \multicolumn{3}{|l|}{ 4. TITLE AND SUBTITLE } & 5. Publication Date \\
\hline \multicolumn{3}{|c|}{$\begin{array}{l}\text { The Effect of Impact Loadings on the Performance of } \\
\text { Wood Joist Subflooring Systems }\end{array}$} & 6. Performing Organization Code \\
\hline \multicolumn{3}{|l|}{ 7. AUTHOR(S) } & $\begin{array}{l}\text { 8. Performing Organization } \\
\text { NBSIR } 73-187\end{array}$ \\
\hline \multicolumn{3}{|c|}{ 9. PERF ORMING ORGANIZATION NAME AND ADDRESS } & $\begin{array}{l}\text { 10. Project/Task/Work Unit No. } \\
4600461\end{array}$ \\
\hline \multicolumn{3}{|c|}{$\begin{array}{l}\text { NAT IONAL BUREAU OF ST ANDARDS } \\
\text { DEPARTMENT OF COMMERCE } \\
\text { WASHINGTON, D.C. } 20234\end{array}$} & $\begin{array}{r}\text { 11. Contract/Grant No. } \\
\text { IAA-H-16-70 }\end{array}$ \\
\hline \multirow{2}{*}{\multicolumn{3}{|c|}{$\begin{array}{l}\text { 12. Sponsoring Organization Name and Address } \\
\text { Office of Research and Technology } \\
\text { Department of Housing and Urban Development } \\
\text { Washington, D. C. } 20410\end{array}$}} & $\begin{array}{l}\text { 13. Type of Report \& Period } \\
\text { Covered } \\
\text { Final } 1\end{array}$ \\
\hline & & & 14. Sponsoring Agency Code \\
\hline
\end{tabular}

16. ABSTRACT ( A 200-word or less factual summary of most significant information. If document includes a significant bibliography or literature surve $y$, mention it here.)

This report presents the results of an experimental study of wood-joist subflooring systems subjected to impact load. Six different types of subflooring systems were tested following the test method described in the ASTM Standard Methods (ASTM Designation E-72). The magnitude of impact load was varied by dropping a 60-1b bag from different heights.

A concentrated static load of $4001 \mathrm{~b}$ was applied to the subfloor after it was exposed to impact load. It is suggested that the deflection under this concentrated load be used as a measure of the impact resistance of the subfloor.

17. KEY WORDS (Alphabetical order, separated by semicolons) Concentrated loads; deflection; floor hardboard; housing; impact energy; Operation BREAKTHROUGH; plywood; subfloors; underlayment; wood; wood joists.

18. AVAILABILITY STATEMENT

X UNLIMITED.

FOR OFFICIAL DISTRIBUTION. DO NOT RELEASE TO NTIS.

\begin{tabular}{|l|l|} 
19. SECURITY CLASS & 21. NO. OF PAGES \\
(THIS REPORT) & \\
UNCL ASSIFIED & \\
\hline $\begin{array}{l}\text { 20. SECURITY CLASS } \\
\text { (THIS PAGE) }\end{array}$ & 22. Price \\
UNCL ASSIFIED &
\end{tabular}




